\title{
IDENTIFIKASI BANJIR IMPOR KENTANG DAN DAMPAKNYA TERHADAP HARGA DOMESTIK KENTANG DI INDONESIA
}

\author{
Hadiwiyono $^{1}$, Muhammad Firdaus ${ }^{2}$, Lukytawati Anggraeni ${ }^{2}$ \\ ${ }^{1}$ Mahasiswa Magister Program Studi Ilmu Ekonomi, FEM IPB \\ ${ }^{2}$ Staf Pengajar FEM IPB
}

Artikel diterima Juli 2013

Artikel disetujui untuk dipublikasikan Desember 2013

\begin{abstract}
Indonesia needed to be cautious of import surge since it has potential to influence import value and price in the era of trade globalization. The main purpose of this reasearch was to examine whether import surge occurred for horticulture commodities in Indonesia, especially for potato. The methods used for identifying occurrence of import surge was based on Special Safeguard Mechanism framework of World Trade Organization which will strengthened with Vector Error Correction Model to analyse the impact of import surge to domestic prices. Based on Special Safeguard Mechanism framework, volume-based Special Safeguard Mechanism triggered in almost all year during 2002-2012 but price-based Special Safeguard Mechanism is not triggered in those years. Based on Impuls Response Function analysis, the impact of import surge shock to domestic price was relatively low but occurred permanently. Based on Forecast Error Variance Decomposition analysis, import surge variables contributed slightly to the domestic price variability but it tend to increased as time.
\end{abstract}

Keywords: Horticulture, Potato, Special Safeguard Mechanism, Import Surge, Vector Error Correction Model

\section{PENDAHULUAN}

\section{Latar Belakang}

Integrasi perekonomian global sedang marak dirintis oleh negara-negara di dunia, terutama pada tingkat regional, misalnya pada tingkat ASEAN. Kerjasama ekonomi ASEAN dimulai dengan disahkannya Deklarasi Bangkok tahun 1967 yang bertujuan untuk memercepat pertumbuhan ekonomi, kemajuan sosial, dan pengembangan budaya. Dalam dinamika perkembangannya, kerjasama ekonomi diarahkan pada pembentukan Komunitas Ekonomi ASEAN (ASEAN Economic Community/AEC) yang pelaksanaannya berjalan relatif lebih cepat. Untuk pembentukan AEC pada tahun 2015, ASEAN menyepakati pewujudannya diarahkan pada integrasi ekonomi kawasan yang implementasinya mengacu pada AEC Blueprint (Kemendag 2012).

Di dalam AEC Blueprint, terdapat berbagai kebijakan sehubungan dengan 
integrasi kawasan ASEAN, diantaranya adalah liberalisasi berbagai faktor ekonomi seperti barang, jasa, investasi, modal, dan tenaga kerja termasuk di dalamnya adalah bebas keluar masuknya faktor-faktor tersebut di dalam kawasan ASEAN. Hal ini merupakan keterbukaan baru bagi Indonesia, berdasarkan AEC Blueprint kemudian diluncurkan ATIGA (ASEAN Trade in Goods Agreement) pada KTT ASEAN ke-14 pada tahun 2009 yang diantara berbagai isinya adalah penghapusan tarif barang. Tentunya hal tersebut menjadi poin positif bagi Indonesia, selain peningkatan efektifitas produksi dan distribusi barang dan jasa, dengan kesiapan daya saing, hal ini dapat meningkatkan pertumbuhan perekonomian Indonesia. Prachason (2009) mengatakan selalu ada argumen bahwa FTA memiliki banyak keunggulan ekonomis walaupun nantinya akan ada resiko kehilangan.

Keterbukaan Indonesia terhadap perdagangan internasional tentunya memiliki resiko. Semakin terbukanya pintu perdagangan internasional terhadap sebuah negara, maka semakin besar pula pengaruh yang berasal dari sisi internasional terhadap perekonomian domestik. Semakin terbuka Indonesia berarti semakin rentan Indonesia terhadap guncangan eksternal (Aminuddin 2009). Faktor eksternal yang dapat memengaruhi perekonomian domestik, terutama yang berbentuk shock (guncangan) seringkali disebut dengan external shock.

External shock sehubungan dengan penghapusan tarif yang perlu diwaspadai adalah peningkatan volume impor secara signifikan sehingga menjadi banjir impor (import surges). Impor pangan pada negara berkembang telah meningkat dan memang diperkirakan terus meningkat seiring dengan peningkatan populasi dan pendapatan, dengan dampak dari peningkatan impor pangan yang berbeda pada setiap negara. Dalam FAO (2011), terdapat kekhawatiran mengenai peningkatan impor pangan dimana volume tersebut menjadi banjir (surge) pada negara berkembang.

Tabel 1 Ekspor Impor Pertanian Indonesia berdasarkan Subsektor tahun 2008-2012 (dalam ribu ton)

\begin{tabular}{|c|c|c|c|c|c|c|}
\hline \multirow{2}{*}{ Vol } & \multicolumn{5}{|c|}{ Tahun } & \multirow{2}{*}{$\begin{array}{c}\text { Growth } \\
\text { Rate } \\
(\%)\end{array}$} \\
\hline & ‘08 & ‘09 & ' 10 & ‘11 & ' 12 & \\
\hline \multicolumn{7}{|c|}{ Sektor Pertanian } \\
\hline $\mathrm{X}$ & 27154 & 29572 & 28768 & 29959 & 30672 & 3.18 \\
\hline M & 12593 & 13401 & 16874 & 22987 & 21735 & 15.75 \\
\hline NX & 14561 & 16171 & 11893 & 7041 & 8937 & -7.32 \\
\hline \multicolumn{7}{|c|}{ Subsektor Tanaman Pangan } \\
\hline $\mathrm{X}$ & 812 & 786 & 892 & 807 & 234 & -17.56 \\
\hline M & 7414 & 7788 & 10504 & 15363 & 14440 & 20.04 \\
\hline NX & -6602 & -7001 & -9612 & -14555 & -14206 & 23.09 \\
\hline \multicolumn{7}{|c|}{ Subsektor Hortikultura } \\
\hline $\mathrm{X}$ & 524 & 447 & 364 & 381 & 426 & -4.18 \\
\hline M & 1429 & 1524 & 1560 & 2052 & 2138 & 11.17 \\
\hline NX & -905 & -1077 & -1196 & -1670 & -1712 & 18.04 \\
\hline \multicolumn{7}{|c|}{ Subsektor Perkebunan } \\
\hline $\mathrm{X}$ & 25182 & 27864 & 27017 & 27863 & 29826 & 4.45 \\
\hline M & 2683 & 2963 & 3578 & 4311 & 3954 & 10.84 \\
\hline $\mathrm{NX}$ & 22498 & 24901 & 2343 & 23551 & 25872 & 3.78 \\
\hline \multicolumn{7}{|c|}{ Subsektor Peternakan } \\
\hline $\mathrm{X}$ & 635 & 473 & 494 & 906 & 185 & -1.34 \\
\hline M & 1065 & 1124 & 1231 & 1190 & 1201 & 4.77 \\
\hline $\mathrm{NX}$ & -429 & -651 & -737 & -283 & -1016 & 18.50 \\
\hline
\end{tabular}

Sumber: Pusdatin Kementan (2013); X: ekspor; $\mathrm{M}$ : impor; NX: net export / balance of trade

Banjir impor ini, untuk beberapa kelompok seperti kelompok populasi masyarakat sebagai konsumen akan diuntungkan karena terdapat alternatif konsumsi barang yang tersedia selain produk lokal, namun di sisi lain, produsen terutama petani yang skalanya kecil akan sangat dirugikan karena munculnya kompetitor. FAO khawatir dalam tahuntahun mendatang impor pangan akan semakin meningkat, mengingat tarif terhadap perdagangan dunia semakin dikikis sehingga pada akhirnya barang impor yang masuk akan berkompetisi 
dengan barang domestik suatu negara dimana barang domestik ini tidak memiliki perlindungan terhadap dampak negatif dari peningkatan banjir impor.

Deteksi banjir impor telah dilakukan di berbagai penelitian. Pada penelitian FAO tahun 2005 telah tercatat terjadinya banjir impor di berbagai negara di dunia. Pada penelitian FAO tahun 2005, banjir impor didefinisikan sebagai deviasi (positif) sebesar 20\% dari total impor.

Potensi banjir impor di Indonesia perlu diteliti lebih lanjut. Secara umum Balance of Trade sektor pertanian Indonesia selama tahun 2008 hingga 2012 adalah trade surplus dengan nilai 14561 528 ton pada tahun 2008, namun nilai positif tersebut semakin menurun dengan tingkat pertumbuhan $-7.32 \%$. Impor pada sektor pertanian pada tahun 2008 tercatat total impor sektor pertanian sebanyak 12 593233 ton yang terus meningkat hingga pada tahun 2012 sebesar 21735483 ton dengan tingkat pertumbuhan $15.75 \%$. Secara mendalam, ekspor impor sektor pertanian 2008 hingga 2012 dapat dilihat pada Tabel 1.

Perdagangan sektor pertanian, kecuali subsektor perkebunan mengalami trade deficit, hal ini menandakan secara umum terjadi impor yang cukup tinggi di sektor ini hingga menyebabkan impor lebih dari ekspor. Impor hortikultura relatif lebih murah, membuat komoditas impor lebih diminati dibandingkan produksi lokal.

\section{Permasalahan}

Tingginya impor hortikultura Indonesia tidak dibarengi dengan kebijakan yang melindungi domestik, terutama harga produsen. Selama tahun 2012, sebagaimana Gambar 1, terpantau impor kentang Indonesia berasal dari berbagai negara di dunia, dimana pasokan terbanyak datang dari negara Belanda sebanyak $23 \%$ dari total volume impor kentang tahun 2012. Pasokan tertinggi berikutnya datang dari Amerika Serikat (13\%) kemudian Australia (125), China (10\%), dan Jerman (9\%). Selain itu terdapat impor dari berbagai negara Selandia Baru, Denmark, Belanda, dan beberapa negara lain dengan share kurang dari satu persen.

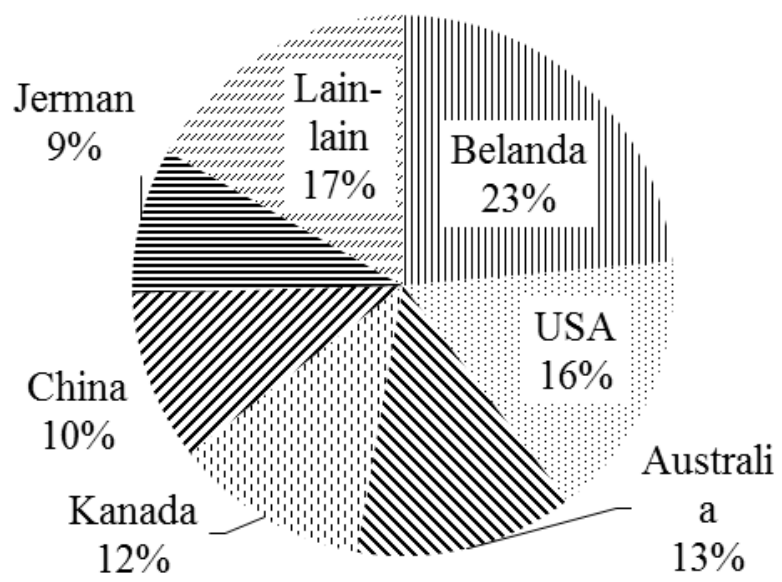

Sumber: Kementan (2013), diolah

Gambar 1 Share impor kentang Indonesia per negara asal tahun 2012

Selama periode 2002 hingga 2012, terpantau tingkat produksi, ekspor, dan impor kentang di Indonesia. Berdasarkan Tabel 2, dari tahun ke tahun, terlihat produksi komoditas kentang cenderung stagnan dengan tingkat produksi berkisar sekitar satu juta ton, dengan penurunan produksi yang signifikan pada tahun 2002 yang cukup rendah sebesar 893824 ton dan pada tahun 2011 sebanyak 955488 ton.

Ekspor kentang Indonesia dari tahun ke tahun selama periode 2002-2012 justru semakin menurun, dimana pada tahun 2002 tercatat ekspor kentang Indonesia sebanyak 27363 ton kemudian semakin menurun hingga akhirnya pada tahun 2012 hanya sebanyak 4936 ton. Sebaliknya, impor kentang Indonesia selama periode 2002-2012 justru meningkat hingga $1994.35 \%$ dengan 
pertumbuhan impor rata-rata sebesar 17 persen.

Peningkatan impor yang signifikan dari tahun 2008 sebesar lima ribu ton menjadi sebelas ribu ton pada tahun 2009 diduga kuat dipengaruhi oleh penurunan tarif impor dari $25 \%$ menjadi $20 \%$. Pada tahun-tahun berikutnya, tarif kentang semakin menurun hingga saat ini dibebaskan dari tarif, sehingga dapat dibayangkan potensi banjir impor kentang yang dapat terjadi dengan kondisi seperti ini.

Tabel 2 Perkembangan total produksi, ekspor, dan impor Indonesia untuk komoditas kentang tahun 2002-2012 (dalam ton)

\begin{tabular}{rrrr}
\hline Tahun & \multicolumn{3}{c}{ Kentang } \\
& Produksi & \multicolumn{1}{c}{ Ekspor } & \multicolumn{1}{c}{ Impor } \\
\hline 2002 & 893824 & 27363 & 2336 \\
2003 & 1009979 & 18656 & 2404 \\
2004 & 1072040 & 16422 & 3148 \\
2005 & 1009619 & 13644 & 5031 \\
2006 & 1011911 & 18607 & 4211 \\
2007 & 1003733 & 9652 & 5559 \\
2008 & 1071543 & 7958 & 5345 \\
2009 & 1176304 & 6308 & 11727 \\
2010 & 1060805 & 6772 & 24204 \\
2011 & 955488 & 5117 & 78419 \\
2012 & 1094240 & 4936 & 46588 \\
\hline
\end{tabular}

Sumber: BPS 2013

Peningkatan impor kentang selama periode 2002-2012 yang terus meningkat harus diteliti lebih lanjut, yang tertuang dalam permasalahan penelitian ini sebagai berikut:

1. Apakah terjadi fenomena banjir impor yang terjadi pada komoditas hortikultura kentang? Seberapa sering frekuensi terjadinya banjir impor untuk komoditas ini?

2. Apakah dampak dari kecendrungan impor kentang yang semakin meningkat terhadap harga domestik kentang di Indonesia?

\section{Tujuan}

Pemberlakuan SSM jika terjadi banjir impor hortikultura Indonesia perlu dibuktikan, dan harus dibuktikan apakah dampak dari banjir impor itu memengaruhi harga domestik selama 2002-2012 yang merupakan era rintisan AFTA. Maka dari itu, penelitian ini bertujuan:

1. Mendeteksi fenomena dan frekuensi banjir impor yang terjadi pada komoditas hortikultura kentang di Indonesia berdasarkan SSM framework.

2. Menganalisis dampak dari shock banjir impor terhadap harga domestik kentang di Indonesia

\section{Ruang Lingkup}

1. Komoditas hortikultura yang diteliti dalam penelitian ini terbatas kepada komoditas kentang.

2. Data yang digunakan dalam penelitian ini adalah data bulanan selama kurun waktu tahun 2002 hingga 2012, yang berasal dari data resmi dari instansi yang bertanggung jawab untuk merilis data statistik.

3. Dampak perekonomian domestik dari penelitian ini dibatasi dari pengamatan terhadap pengaruh-pengaruh faktor eksternal, seperti harga internasional, harga impor, dan volume impor, tanpa mempertimbangkan pengaruh dari dalam negeri. Hal ini dilakukan agar dapat terlihat jelas pengaruh faktor eksternal akibat keterbukaan ekonomi baik dalam jangka pendek maupun jangka panjang.

\section{METODE PENELITIAN}

\section{Cakupan Komoditas dan Sumber Data}

Penelitian ini akan menggunakan data time series bulanan komoditas kentang dengan periode 2002-2012. Pemilihan periode waktu ini didasari atas 
aktifnya Indonesia dalam perdagangan internasional AFTA yang diprediksi juga memicu keterbukaan Indonesia lebih lanjut untuk impor.

Tabel 3. Data Utama Penelitian

\begin{tabular}{clccc}
\hline No & Variabel & Satuan & Simbol & Sumber \\
\hline 1 & Harga & $\mathrm{Rp} / \mathrm{kg}$ & $\mathrm{PW}$ & $\begin{array}{r}\text { World } \\
\text { Bank, } \\
\text { Dunia }\end{array}$ \\
2 & $\begin{array}{l}\text { Harga } \\
\text { Impor }\end{array}$ & $\mathrm{Rp} / \mathrm{kg}$ & $\mathrm{PM}$ & $\begin{array}{r}\text { USDA } \\
\text { BPS }\end{array}$ \\
3 & $\begin{array}{l}\text { Volume } \\
\text { Impor }\end{array}$ & $\mathrm{kg}$ & $\mathrm{QM}$ & $\mathrm{BPS}$ \\
4 & $\begin{array}{l}\text { Harga } \\
\text { Konsumen } \\
5\end{array}$ & $\mathrm{Rp} / \mathrm{kg}$ & $\mathrm{PC}$ & $\mathrm{BPS}$ \\
& $\begin{array}{l}\text { Harga } \\
\text { Produsen }\end{array}$ & $\mathrm{Rp} / \mathrm{kg}$ & $\mathrm{PF}$ & $\mathrm{BPS}$ \\
\hline
\end{tabular}

Tabel 3 menjabarkan data utama yang akan digunakan dalam model penelitian.Selain data pada tabel diatas, terdapat data-data sekunder pelengkap yang berasal dari Bank Indonesia, FAO, Kementan, dan instansi penyedia data relevan lainnya.

\section{Analisis Dampak Guncangan Banjir Impor terhadap Harga Domestik}

Berdasarkan Setiyanto (2011) yang mengadaptasi dari McCarthy (2000), konstruksi model untuk menganalisis banjir impor dibangun dengan tiga tahapan. Pertama, supply dan demand shock dari pasar dunia dapat menyebabkan banjir impor dapat diidentifikasikan dengan perubahan harga komoditas dunia. Kedua, adanya shock tersebut akan mengubah harga dan volume impor, kemudian tertransmisikan ke dalam pasar domestik dengan perubahan harga konsumen pasar domestik. Ketiga, perubahan harga konsumen di pasar domestik kemudian memicu perubahan permintaan dan penawaran pasar domestik antara produksi dan konsumsi sehingga kemudian terjadi perubahan harga produsen. Ketiga tahapan ini kemudian dirumuskan kembali ke dalam model dasar, dengan penjabaran sebagai berikut:

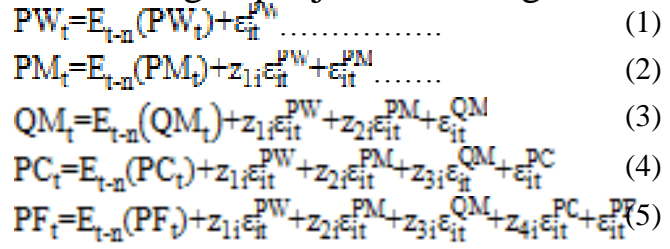
sebelumnya

$\mathrm{z}_{\mathrm{ij}}=$ restriksi variabel $\mathrm{i}$ terhadap variabel $\mathrm{j}$

$\varepsilon_{\mathrm{it}}^{\mathrm{j}}=$ vector orthogonal shocks variabel $\mathrm{j}$ yang diakibatkan oleh variabel i pada waktu t

Model SVAR akan digunakan apabila data-data penelitian stasioner pada level, apabila data tersebut tidak stasioner pada level namun tidak terkointegrasi, maka akan digunakan model VAR first difference. Opsi lain adalah menggunakan model VECM apabila data-data penelitian yang digunakan tidak stasioner pada level dan terkointegrasi.

\section{Impulse Respons Function}

Impulse Respons Function (IRF) adalah suatu metode yang digunakan untuk menentukan respon suatu variabel endogen terhadap suatu shock tertentu. Hal ini dikarenakan shock variabel misalnya ke-i tidak hanya berpengaruh terhadap variabel ke-i itu saja tetapi ditransmisikan kepada semua variabel endogen lainnya melalui struktur dinamis atau struktur lag. Dengan kata lain IRF mengukur pengaruh suatu shock pada suatu waktu kepada inovasi variabel 
endogen pada saat tersebut dan di masa yang akan datang (Firdaus 2011).

Pada penelitian ini IRF digunakan untuk menggambarkan dampak dari guncangan banjir impor komoditas kentang berupa kenaikan volume impor dan penurunan harga impor terhadap harga domestik.

\section{Forecast Error Variance Decomposition}

Firdaus (2011) menjelaskan Forecast Error Variance Decomposition (FEVD) adalah metode yang dilakukan untuk melihat bagaimana perubahan suatu variabel yang ditunjukkan oleh perubahan error variance dipengaruhi oleh variabelvariabel lainnya. Metode ini mencirikan suatu struktur dinamis dalam model VAR/VECM. Dalam metode ini dapat dilihat kekuatan dan kelemahan masingmasing variabel dalam memengaruhi variabel lainnya dalam kurun waktu yang panjang.

FEVD merinci ragam dari peramalan galat menjadi komponenkomponen yang dapat dihubungkan dengan setiap variabel endogen dalam model. Dengan menghitung persentase kuadrat prediksi galat k-tahap ke depan dari sebuah variabel akibat inovasi dalam variabel-variabel lain maka dapat dilihat seberapa besar perbedaan antara error variance sebelum dan sesudah terjadinya shock yang berasal dari dirinya sendiri maupun dari variabel lain. Melalui FEVD dapat diketahui secara pasti faktor-faktor yang memengaruhi fluktuasi dari variabel tertentu.

FEVD pada penelitian ini digunakan untuk melihat kontribusi banjir impor dalam pembentukan harga domestik kentang, dimana secara umum terjadi peningkatan impor kentang dari tahun ke tahun.

\section{Analisis Deteksi Banjir Impor}

Berdasarkan draft Modalities pada Juli 2008, SSM dibagi menjadi dua jenis yaitu Volume-based SSM dan Price-based SSM. Volume-based SSM dapat dimulai dengan rata-rata impor dalam tiga tahun terakhir, yang kemudian dijadikan sebagai base imports (apabila tahun dasar yang digunakan adalah 2013, maka trigger safeguard akan terjadi apabila impor meningkat sebesar tingkat tertentu dibandingkan dengan rata-rata impor yang terjadi pada tahun 2010-2012). Berdasarkan draft Modalities revisi Desember 2008, trigger dan remedy dari volume-based SSM dibagi menjadi tiga jenis, yaitu:

A. Ketika volume impor bernilai $110 \%$ namun tidak melebihi $115 \%$ (peningkatan volume 10 hingga 14.99\%) terhadap base imports. Maka remedy yang digunakan adalah peningkatan tarif maksimal sebesar $25 \%$ dari bound tariff saat ini yang ditambahkan ke dalam applied tariff, atau 25 poin persentase ditambahkan ke dalam applied tariff secara langsung. Pilihan ditentukan dari tarif mana yang lebih besar ${ }^{1}$.

B. Ketika volume impor bernilai $115 \%$ namun tidak melebihi $135 \%$ (peningkatan volume 15 hingga $34.99 \%)$ terhadap base imports. Maka remedy yang digunakan adalah peningkatan tarif maksimal sebesar $40 \%$ dari current bound tariff ditambahkan ke dalam applied tariff, atau 40 poin persentase ditambahkan ke dalam applied tariff secara langsung. Pilihan ditentukan dari tarif mana yang lebih besar.

\footnotetext{
${ }^{1}$ Misalkan negara X memiliki $60 \%$ bound tariff dan $30 \%$ applied tariff, negara tersebut memiliki dua pilihan yaitu:

$$
\begin{gathered}
(25 \% * 60 \%)+30 \%=45 \% \text { atau } \\
25 \%+30 \%=55 \%
\end{gathered}
$$

Maka pada saat terjadi peningkatan volume impor 10-15 persen, tarif akan dinaikkan sebesar 55\%

Sumber:

http://www.wto.org/english/tratop_e/agric_e/guide _agric_safeg_e.htm
} 
C. Ketika volume impor bernilai melebihi $135 \%$ (peningkatan volume lebih dari $35 \%$ ) terhadap base imports. Maka remedy yang digunakan adalah penerapan tarif sebesar $50 \%$ dari bound tariff saat ini yang ditambahkan ke dalam applied tariff, atau 50 poin persentase ditambahkan ke dalam applied tariff secara langsung. Pilihan ditentukan dari tarif mana yang lebih besar.

Namun perlu diingat, volume-based SSM tidak dapat berlaku ketika volume impor bersifat negligible secara nyata terhadap produksi dan konsumsi domestik (berdasarkan draft Modality revisi Desember 2008 pasal 131), namun berdasarkan G-33, tidak ada pembatasan sifat manifestly negligible dari produk impor yang akan diberlakukan SSM.

Bedasarkan pasal 140 draft yang sama, Volume-based SSM dapat diterapkan dapat diterapkan selama maksimum 12 bulan dari awal permohonan penerapan safeguard, kecuali jika produk bersifat musiman, maka SSM berlaku selama enam bulan atau selama periode musiman berlaku. Untuk penerapan SSM berikutnya pada produk yang sama, maka rata-rata dari volume impor tiga tahun akan menggunakan base imports pada tahun yang baru tersebut, kecuali base imports tahun baru tersebut lebih kecil dari tahun penerapan sebelumnya. Setelah pemberlakuan dua periode SSM terhadap produk yang sama, maka produk tersebut tidak boleh memberlakukan SSM selama dua periode ke depan.

Price-based SSM dimulai dari penentuan rata-rata tingkat harga impor selama tiga tahun sebelumnya sebagai starting point harga referensi. Trigger price-based SSM adalah penurunan harga sebesar $15 \%$ atau lebih (85\% atau kurang dari harga referensi). Tarif yang diberlakukan tidak lebih dari $85 \%$ gap antara harga impor dan harga trigger.

\section{PEMBAHASAN}

\section{Definisi Banjir Impor (Import Surges)}

Definisi umum atau konvensional terhadap banjir impor (import surge) dapat dikatakan tidak ada. Berdasarkan definisi kamus tentang kata surge dalam bahasa Inggris digunakan untuk menggambarkan peningkatan yang mendadak, tajam, dan tidak diduga dalam variabel yang dipertanyakan. Persetujuan WTO dalam general trade remedy measures mendefinisikan banjir impor lebih umum dibandingkan dengan istilah kamus, sebagaimana pada Pasal 2 dalam Agreement of Safeguards (ASG) yang mendefinisikan komoditas tertentu dalam fenomena banjir impor (dalam artian penerapan safeguards terhadap komoditas yang dapat memicu):

"When a product is imported into a country in such increased quantities, absolute or relative to domestic production, and under such conditions as to cause or threaten to cause serious injury to domestic industry that produce like or directly competitive products". (WTO 2013²)

Sehingga definisi banjir impor dalam penelitian ini adalah fenomena yang terjadi ketika peningkatan volume (atau harga) dari impor yang melebihi tingkat normal pada suatu periode waktu berdasarkan kriteria tertentu. Walaupun tidak terdapat kriteria tertentu yang pasti, namun biasanya kriteria yang dimaksud adalah durasi dari surge tersebut, sebagaimana jumlah impor dibandingkan dengan tingkat normalnya. Secara umum, WTO tidak menyebutkan istilah banjir impor, namun persyaratan dalam safeguard sering didefinisikan sebagai fenomena tersebut (FAO 2011). Berdasarkan studi FAO tahun 2011 (De Nigris 2005; Mosoti dan Sharma 2005; dan Sharma 2005) dibangun kesimpulan

\footnotetext{
${ }^{2}$ Interpretation and Application of Article XIX pasal 798.
} 
bahwa banjir impor adalah peningkatan impor yang mendadak dan pada umumnya jangka pendek, namun dapat dengan mudah berdampak negatif terhadap peningkatan tren pada jangka panjang ataupun berkorelasi dengan faktor-faktor lain di dalam indikator pasar.

\section{Special Safeguard}

Pembentukan proteksi petani lokal terhadap banjir impor berbentuk SSM telah dirintis sejak tahun 1994. Pada prosesnya terdapat tiga jenis safeguard yang telah dibentuk dalam proses yang pada akhirnya menjadi SSM, yaitu GATT 1994 article XIX, SSG, sampai kepada SSM.

\section{- GATT 1994 Article XIX}

GATT 1994 Article XIX memiliki 3 pasal yang pada umumnya membicarakan mengenai aksi "darurat" yang perlu dilakukan terhadap impor produk tertentu. Perlakuan khusus dilakukan apabila terjadi suatu kasus impor produk tertentu dimana peningkatan volume impor (yang dapat disertai dengan penurunan harga) tersebut dapat menimbulkan dampak buruk bagi produsen domestik dengan produksi produk yang sama, produk impor tersebut kemudian diposisikan sebagai produk pesaing secara langsung maupun tidak langsung. Article XIX tidak membicarakan secara spesifik mengenai produk apa yang perlu diberikan perlakuan khusus, sehingga dapat disimpulkan bahwa tidak ada batasan mengenai produk yang dipilih untuk diberikan proteksi. Perlu diketahui pada framework safeguards versi Article XIX, trigger terjadinya proteksi hanya berlaku terhadap peningkatan volume saja, apabila terjadi penurunan harga tanpa disertai dengan peningkatan volume, maka trigger tersebut tidak berlaku.

Article XIX dalam GATT 1994 dalam pasal 2 dan 3 mengatakan bahwa negara anggota WTO yang merasa bahwa suatu produk tersebut sudah menimbulkan dampak buruk bagi produsen lokal dapat melakukan tindakan pembatasan kuantitas (kuota) maupun peningkatan tarif. Hal ini dilakukan berdasarkan persetujuan antara negara pengekspor dan negara pengimpor dalam koridor pengawasan WTO, dimana terjadi kompensasi terhadap negosiasi tersebut. Tidak ada batasan waktu pemberlakuan perlakuan khusus dari produk tersebut selama kontrak berlaku disetujui. Aplikasi dari Article XIX pernah dilakukan oleh dua negara yang diketahui (WTO 1999), yaitu Argentina untuk produk sepatu (footwear) dan Korea untuk produk peternakan (dairy).

\section{- Special Agricultural Safeguard (SSG)}

SSG merupakan bentuk respon tindak lanjut atas GATT 1994, yang kemudian tercantum di dalam Article 5 Agreement of Agriculture tentang Special Safeguard Provisions. Special Safeguards Provisions berbeda dengan safeguard umum, dimana untuk pertanian safeguards dapat berlaku secara otomatis apabila nilai impor meningkat pada tingkat tertentu atau harga menurun sampai kurang dari tingkat tertentu, dan tidak perlu dilakukan pembuktian adanya dampak buruk yang telah terjadi pada produsen lokal akibat dari perubahan tersebut.

SSG hanya dapat dilakukan terhadap produk pertanian yang telah diberikan "tarif" (yang berjumlah kurang dari $20 \%$ dari total produk pertanian), dimana tarif tersebut merupakan restriksi kuantitatif yang dikonversi kedalam tarif yang setara kemudian dipotong. SSG tidak dapat diberlakukan terhadap impor yang berada dalam kuota tarif dan hanya dibatasi kepada beberapa pemerintah negara tertentu, belum lagi banyak negara berkembang yang memilih untuk tidak mengikuti "tarif" sehingga negara tersebut tidak diberikan hak untuk melakukan SSG. Pada prakteknya, hanya sedikit negara 
yang menerapkan SSG. Indonesia sendiri memiliki hak untuk memberlakukan SSG terhadap 14 produk (kode HS 8 digit berdasarkan kode HS, namun secara umum merupakan empat produk (kode HS 4 digit) yaitu, susu (HS0402), mentega (HS0403), lemak susu (HS0405), dan cengkeh (HS0907).

\section{- Special Safeguard Mechanism (SSM)}

Pembatasan terhadap negara-negara yang diberikan hak menerapkan SSG dan kondisi negara berkembang yang tidak menginginkan pemberlakuan "tarif" kemudian mendorong pembuatan rumusan kebijakan baru yang memiliki sistem seperti SSG namun dapat diberlakukan terhadap negara berkembang yang sebelumnya tidak mendapatkan hak. Safeguard baru tersebut dirancang bernama Special Safeguards Mechanism yang tercantum dalam Draft Modalities for Agriculture milik WTO pada tahun 2008.

Konsep dasar SSM sangat mirip dengan SSG, namun dengan pencabutan pembatasan terutama masalah "tarif" yang kemudian dicantumkan dalam draft Modalities for Agriculture pada pasal 123. SSM memberlakukan tarif terhadap produk-produk impor yang mengalami peningkatan volume impor (banjir impor) atau penurunan tingkat harga produk impor, dengan pemberlakuan tarif yang bersifat sementara. Namun SSM dapat diberlakukan oleh semua negara berkembang dan negara tersebut berhak melakukan dalam rangka proteksi produsen lokal untuk semua produk pertanian tanpa harus membuktikan adanya injury.

Berdasarkan draft Modalities pada Juli 2008, SSM dibagi menjadi dua jenis yaitu Volume-based SSM dan Price-based SSM. Trigger volume-based SSM dibagi menjadi tiga jenis, yaitu:

1. Ketika volume impor bernilai $110 \%$ namun tidak melebihi $115 \%$ (peningkatan volume 10 hingga 15\%) terhadap base imports

2. Ketika volume impor bernilai $115 \%$ namun tidak melebihi $135 \%$ (peningkatan volume 15 hingga 35\%) terhadap base imports.

3. Ketika volume impor bernilai melebihi $135 \%$ terhadap base imports

Namun perlu diingat, volume-based SSM tidak dapat berlaku ketika volume impor bersifat negligible secara nyata terhadap produksi dan konsumsi domestik (berdasarkan draft Modelity revisi Desember 2008 pasal 131), namun berdasarkan G-33, tidak ada pembatasan sifat manifestly negligible dari produk impor yang akan diberlakukan SSM.

Bedasarkan pasal 140 draft yang sama, Volume-based SSM dapat diterapkan dapat diterapkan selama maksimum 12 bulan dari awal permohonan penerapan safeguard, kcuali jika produk bersifat musiman, maka SSM berlaku selama enam bulan atau selama periode musiman berlaku. Untuk penerapan SSM berikutnya pada produk yang sama, maka rata-rata dari volume impor tiga tahun akan menggunakan base imports pada tahun yang baru tersebut, kecuali base imports tahun baru tersebut lebih kecil dari tahun penerapan sebelumnya. Setelah pemberlakuan dua periode SSM terhadap produk yang sama, maka produk tersebut tidak boleh memberlakukan SSM selama dua periode ke depan.

Price-based SSM dimulai dari penentuan rata-rata tingkat harga impor selama tiga tahun sebelumnya sebagai starting point harga referensi. Trigger price-based SSM adalah penurunan harga sebesar $15 \%$ atau lebih (85\% atau kurang dari harga referensi). Tarif yang diberlakukan tidak lebih dari $85 \%$ gap antara harga impor dan harga trigger. 


\section{Estimasi Model}

Sebelum memasuki pembentukan model yang digunakan dalam analisis untuk penelitian, terlebih dahulu dilakukan pengujian pra-estimasi. Tujuan dari pengujian pra-estimasi adalah untuk memastikan penggunaan model yang paling tepat. Nilai ini penting dilakukan agar analisis berdasarkan model dapat menghasilkan hasil yang valid dan andal.

\section{Uji Stasioneritas Data}

Metode yang digunakan untuk menguji kestasioneran data untuk penelitian ini adalah dengan Augmented Dickey-Fuller Test atau uji ADF. Uji ADF yang dilakukan pada penelitian ini membandingkan antara nilai $t$-statistics yang dihasilkan oleh variabel dengan critical value pada level 1 persen, 5 persen, dan 10 persen. Jika nilai mutlak $t$ statistics lebih besar dibandingkan dengan nilai mutlak critical value, maka data tersebut memiliki unit root, atau dengan kata lain data tersebut tidak stasioner pada tingkat tersebut, maka harus dilakukan differencing terhadap data hingga data tersebut tidak memiliki unit root lagi.

Penelitian yang menggunakan data tidak stasioner dapat menghasilkan regresi semu (spurious regression), hal tersebut dapat berakibat kepada analisis yang meleset, misalkan regresi menggambarkan hubungan satu variabel dengan variabel lain yang signifikan secara statistik, namun pada kenyataannya tidak demikian. Hal ini sangat beresiko terhadap adanya missleading dari kesimpulan penelitian. Tabel 4 secara mendalam membandingkan pengujian stasioneritas data berdasarkan uji ADF. Hasil pengujian akar unit (unit root) untuk data penelitian menunjukkan bahwa pada komoditas kentang, hanya Harga Impor (PM) Kentang yang stasioner pada level.
Tabel 4 Hasil Pengujian Akar Unit berdasarkan Augmented Dickey-Fuller Test

\begin{tabular}{clccc}
\hline \multirow{2}{*}{ Variabel } & \multicolumn{2}{c}{ Level } & \multicolumn{2}{c}{ First difference } \\
\cline { 2 - 5 } & $\mathrm{t}$-stat & Hasil & $\mathrm{t}$-stat & Hasil \\
\hline PW & -2.41 & TS & -9.68 & $\mathrm{~S}$ \\
QM & -2.49 & TS & -12.30 & $\mathrm{~S}$ \\
PM & $-6.87^{*}$ & TS & -10.37 & $\mathrm{~S}$ \\
PC & -0.07 & TS & -9.53 & $\mathrm{~S}$ \\
PF & -0.55 & TS & -9.23 & $\mathrm{~S}$
\end{tabular}

Sumber: Lampiran 1 hingga 6; PW=harga dunia, $\mathrm{QM}=$ volume impor, $\mathrm{PM}=$ harga impor, $\mathrm{PC}=$ harga konsumen, $\mathrm{PF}=$ harga produsen; Nilai $t$-statistics ADF dibandingkan dengan critical value dari uji ADF, dimana critical value $1 \%$ level adalah 3.481623 , 5\% level adalah -2.883930 , dan $10 \%$ level adalah -2.578788; TS: tidak stasioner; S: stasioner

Data penelitian kemudian diuji akar unitnya pada tingkat first difference. Berdasarkan Tabel 4, semua variabel yang digunakan pada penelitian sudah stasioner, artinya tidak terdapat akar unit di dalam data penelitian tersebut. Penggunaaan data first difference pada penelitian memiliki kekurangan karena informasi jangka panjang pada penelitian menjadi hilang, namun terdapat resiko lain seperti yang sudah disebutkan sebelumnya jika menggunakan data level yang tidak stasioner. Maka berdasarkan uji stasioneritas pada data yang digunakan, VAR pada level tidak dapat digunakan karena sebagian besar data tidak stasioner pada level, kemungkinan penelitian dapat dilakukan dengan dua metode yaitu VAR first difference atau VECM.

\section{Penentuan Selang Optimal}

Penentuan selang optimal dalam mengestimasi model VAR penting dilakukan guna menghindari masalah autokorelasi. Terdapat beberapa indikator untuk menggambarkan lag optimal yang dapat menjadi acuan, diantaranya Likelihood Ratio (LR), Final Prediction Error (FPE), Akaika Information Criterion (AIC), Schawrz Information Criterion (SC), ataupun Hannan-Quinn Criterion 
(HQ). Pada penelitian ini digunakan SC sebagai penguji lag optimal.

Tabel 5 Hasil Pengujian Selang (Lag) Optimal

\begin{tabular}{cc}
\hline & \multicolumn{2}{c}{ Schwarz Information Criterion (SC) ${ }^{\mathrm{a}}$} \\
\cline { 2 - 3 } $\mathrm{Lag}$ & Kentang \\
\hline 0 & -0.279251 \\
1 & $-7.645999^{*}$ \\
2 & -7.225419 \\
3 & -6.669992 \\
4 & -5.997455 \\
5 & -5.430943 \\
6 & -4.724518 \\
7 & -3.982587 \\
8 & -3.372294 \\
\hline${ }^{a}$ tanda bintang (*) menandakan berdasarkan SC, \\
model optimal pada lag 1
\end{tabular}

Tabel 5 memperlihatkan bahwa berdasarkan Schwarz Information Criterion, untuk model kentang yang akan dianalisis, semua model optimal pada lag pertama. Secara umum, variabel-variabel yang diteliti saling memengaruhi tidak hanya pada periode saat ini, namun terkait pula pada periode sebelumnya.

\section{Pengujian Stabilitas VAR}

Tahap selanjutnya

didapatkan lag optimal, dilakukan pengujian stabilitas model VAR. Uji stabilitas VAR dilakukan untuk menjamin validitas dari analisis innovation accounting, yaitu Impulse Response Function (IRF) dan Forecast Error Variance Decomposition (FEVD). Analisis IRF dan FEVD dalam model VAR menjadi tidak valid ketika model tersebut tidak stabil pada tingkat lag tertentu.

Tabel 6 Hasil Pengujian Stabilitas Vector Auto Regression

$\begin{array}{r}\hline \text { Modulus } \\ \hline 0.997464 \\ 0.86867 \\ 0.86867 \\ 0.317719 \\ 0.281571 \\ \hline\end{array}$

Pengujian stabilitas VAR dilakukan dengan menghitung akar-akar dari fungsi polinomial atau disebut juga roots of characterstics polinomial. Stabilitas a model dilihat dari modulus yang bernilai kurang dari satu pada seluruh akar (roots) pada sistem VAR tersebut. Tabel 6 menunjukkan bahwa ketiga model yang akan disusun sudah stabil pada lag optimalnya yaitu lag pertama. Pada model VAR komoditas kentang, kisaran modulus ada diantara $0.2816-0.9975$.

\section{Pengujian Kointegrasi}

Pengujian terakhir untuk praestimasi adalah pengujian kointegrasi. Pengujian kointegrasi yang dimaksud adalah menguji apakah variabel-variabel yang tidak stasioner pada level terkointegrasi atau tidak. Uji kointegrasi bertujuan untuk menentukan apakah kelompok dari variabel-variabel yang tidak stasioner pada level memenuhi persyaratan proses integrasi, yaitu proses dimana semua variabel telah stasioner pada derajat yang sama yaitu pada first difference.

Pengujian kointegrasi biasanya dilakukan dengan Johansen Cointegration Test. Kriteria dari pengujian ini didasarkan kepada trace statistics yang didapatkan dari Johansen Cointegration Test. Jika nilai trace statistic lebih dari critical value lima \% maka hipotesis alternatif (H1) yang menyatakan jumlah rank kointegrasi tidak dapat ditolak atau dengan kata lain tolak hipotesis awal $(\mathrm{H} 0)$, maka pada rank tersebut telah terjadi kointegrasi.

Tabel 7 menunjukkan hasil pengujian kointegrasi untuk komoditas kentang, terjadi kointegrasi sebanyak tiga hubungan. Terjadinya hubungan kointegrasi dapat dilihat lebih dalam dengan perbandingan nilai trace statistic yang lebih dari nilai kritis $5 \%$. keberadaan hubungan kointegrasi pada data komoditas tersebut menunjukkan bahwa pada jangka panjang terjadi hubungan 
antar variabel dalam masing-masing model sehingga tidak dimungkinkan menggunakan model VAR maupun VAR first difference pada penelitian ini.

Tabel 7 Hasil Pengujian Kointegrasi Data

\begin{tabular}{cccr}
\hline \multicolumn{2}{c}{ Hipotesis } & Trace Statistic & \multicolumn{1}{c}{$\begin{array}{c}5 \% \\
\text { Critical } \\
\text { Value }\end{array}$} \\
$\mathrm{H} 0$ & $\mathrm{H} 1$ & Kentang & 60.06141 \\
$\mathrm{R}=0$ & $\mathrm{R} \geq 1$ & $106.2031 *$ & 40.17493 \\
$\mathrm{R} \leq 1$ & $\mathrm{R} \geq 2$ & $59.48478^{*}$ & 24.27596 \\
$\mathrm{R} \leq 2$ & $\mathrm{R} \geq 3$ & $29.53688^{*}$ & 12.3209 \\
$\mathrm{R} \leq 3$ & $\mathrm{R} \geq 4$ & 12.07155 & 4.129906 \\
$\mathrm{R} \leq 4$ & $\mathrm{R} \geq 5$ & 2.538372 & \\
* menunjukkan trace statistics lebih dari critical \\
value 5\% atau terjadi kointegrasi
\end{tabular}

Kesimpulan yang didapatkan pada pengujian pra-estimasi adalah pertama, untuk model sebagian besar data tidak stasioner pada level namun stasioner pada first difference. Kedua, model tersebut optimal pada lag pertama dan sudah stabil pada lag tersebut. Ketiga, model tersebut masing-masing memiliki hubungan kointegrasi didalamnya. Berdasarkan tiga poin ini maka model yang cocok untuk digunakan pada tiga model komoditas hortikultura adalah model Vector Error Correction Model (VECM).

\section{Deteksi Banjir Impor Volume-Based SSM}

Berdasarkan framework SSM revisi Desember 2008 dari Draft Modalities for Agriculture WTO, banjir impor berupa peningkatan volume impor secara signifikan, berdasarkan draft modalities for agriculture untuk SSM dapat terpicu apabila volume impor meningkat sampai tingkat tertentu melebihi base import. Base import dapat digambarkan dengan volume impor rata-rata tiga tahun terakhir atau dengan kata lain three year moving average dari volume impor komoditas tertentu. Peningkatan tersebut secara spesifik dibagi menjadi tiga tingkat yaitu mulai dari melebihi $110 \%$ hingga $114.99 \%$, $115 \%$ hingga $134.99 \%$ dan lebih dari $135 \%$ dengan tingkatan kemudian mewakili remedy yang dapat diberlakukan yang akan dibahas lebih lanjut dalam sub bab berikutnya.

Untuk memudahkan pembagian, pada penelitian ini digunakan Trigger A untuk menggambarkan peningkatan antara $110 \%$ hingga $114.99 \%$, Trigger B untuk menggambarkan peningkatan antara 115\% hingga $134.99 \%$ dan Trigger C untuk menggambarkan peningkatan diatas $135 \%$. Berdasarkan pendekatan tersebut maka disusunlah tabel perbandingan volume impor dengan base import.

Pada tahun 2004 nilai volume impor adalah $3148342 \mathrm{~kg}$ atau $127.3 \%$ lebih tinggi dari base import tahun 2004 yang hanya sebesar 2473174 sehingga pada tahun 2004 terpicu banjir impor untuk peningkatan volume impor sesuai dengan volume-based SSM untuk kategori Trigger B.

Tabel 8. Volume-based SSM Komoditas Kentang

\begin{tabular}{rcrrr}
\hline Thn & $\begin{array}{c}\text { Volume } \\
\text { Impor } \\
\text { ton) }\end{array}$ & $\begin{array}{c}\text { Base } \\
\text { Import } \\
\text { (ton) })^{\mathrm{a}}\end{array}$ & $\begin{array}{c}\text { Perubah } \\
\text { an } \\
(\%)\end{array}$ & $\begin{array}{c}\text { Trigg } \\
\text { er }\end{array}$ \\
\hline 2002 & 2336 & 3474 & 67.24 & - \\
2003 & 2404 & 3194 & 75.26 & - \\
2004 & 3148 & 2473 & 127.30 & B \\
2005 & 5031 & 2629 & 191.33 & C \\
2006 & 4210 & 3528 & 119.35 & B \\
2007 & 5559 & 4130 & 134.60 & B \\
2008 & 5345 & 4933 & 108.34 & - \\
2009 & 11727 & 5038 & 232.76 & C \\
2010 & 24203 & 7543 & 320.84 & C \\
2011 & 78418 & 13758 & 569.96 & C \\
2012 & 46587 & 38116 & 122.22 & B \\
\hline
\end{tabular}

Sumber: BPS (2013), diolah; adihitung berdasarkan three year moving average

Pada Tabel 8, untuk komoditas kentang terjadi banjir impor sebanyak tujuh kali selama periode 2002-2012, dimana terdapat tiga tahun $(2002,2003$, dan 2008) volume impor dapat dikatakan tidak melonjak naik. Namun pada tujuh tahun lainnya, sebanyak empat kategori 
trigger $\mathrm{B}$ dan empat kategori trigger $\mathrm{C}$ yang terpicu oleh peningkatan volume impor dibandingkan dengan base importnya..

Pada tahun 2002, impor komoditas kentang hanya sebanyak $2336447 \mathrm{~kg}$ menjadi $46587879 \mathrm{~kg}$ pada tahun 2012 . Banjir impor yang sangat parah terjadi pada tahun 2011 dimana impor tahun tersebut sebesar $\quad \begin{array}{lllll}78 & 418 & 905 & \mathrm{~kg}\end{array}$ dibandingkan tahun sebelumnya yang hanya $24203560 \mathrm{~kg}$ saja. Akibatnya jika dibandingkan dengan base import tahun 2011 terjadi peningkatan 569.96\% sehingga sangat jelas terlihat bahwa terjadi banjir impor yang sangat parah pada tahun tersebut.

\section{Deteksi Banjir Impor Price-Based SSM}

Harga impor kentang selama tahun 2002 hingga 2012 tidak mengalami penurunan yang signifikan sehingga tidak memicu trigger price-based SSM. Pada Tabel 9 dapat dilihat penurunan harga dibanding dengan reference price hanya terjadi pada tahun 2002 dengan penurunan sebesar $3.31 \%$, jauh dibawah trigger price based SSM sebesar $15 \%$.

Tabel 9. Price-based SSM Komoditas Kentang

\begin{tabular}{cccc}
\hline Thn & $\begin{array}{c}\text { Harga } \\
\text { Impor } \\
(\$ \mathrm{US} / \mathrm{kg})\end{array}$ & $\begin{array}{c}\text { Reference } \\
\text { Price } \\
(\$ \mathrm{US} / \mathrm{kg})^{\mathrm{a}}\end{array}$ & $\begin{array}{c}\text { Perubah } \\
\text { an } \\
(\%)\end{array}$ \\
\hline 2002 & 0.39 & 0.40 & 96.69 \\
2003 & 0.42 & 0.41 & 102.74 \\
2004 & 0.51 & 0.44 & 115.28 \\
2005 & 0.46 & 0.44 & 105.19 \\
2006 & 0.52 & 0.46 & 112.56 \\
2007 & 0.57 & 0.50 & 115.48 \\
2008 & 0.54 & 0.52 & 104.15 \\
2009 & 0.56 & 0.55 & 102.02 \\
2010 & 0.61 & 0.56 & 108.72 \\
2011 & 0.61 & 0.57 & 107.15 \\
2012 & 0.62 & 0.59 & 104.97 \\
\hline
\end{tabular}

Sumber: BPS (2012), diolah; adihitung berdasarkan three year moving average
Pembentukan perubahan harga impor dibandingkan dengan reference price selama periode 2002 hingga 2012 memiliki kecenderungan stabil dengan tingkat peningkatan sekitar enam persen. Studi menunjukkan bahwa peningkatan volume impor kentang tidak diikuti dengan penurunan harga impor kentang.

\section{Dampak Banjir Impor terhadap Harga Domestik \\ Impulse Response Function dari} ketiga model VECM dapat dimanfaatkan untuk menggambarkan dampak dari import surge terhadap pembentukan harga domestik. Gambar 2 menunjukkan banjir impor berupa guncangan peningkatan volume impor kentang memengaruhi harga domestik kentang. Pada dua periode awal, harga kentang domestik harga meningkat, hal ini disebabkan pada umumnya impor kentang terjadi pada saat supply kentang di Indonesia menurun, yaitu sebelum masa panen kentang Indonesia.

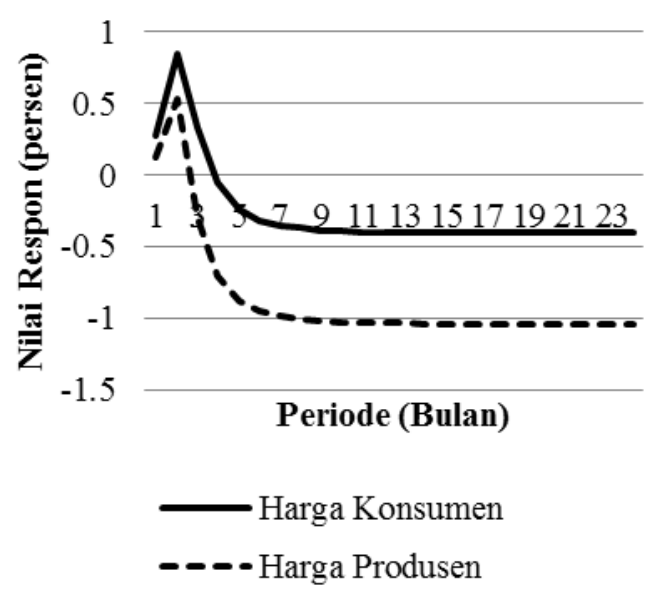

Gambar 2. Guncangan Peningkatan Volume Impor Kentang terhadap Harga Domestik Kentang

Volume impor yang masuk ke pasar memiliki gap waktu untuk memenuhi supply kentang untuk masyarakat 
sehingga pada periode awal terlihat penyesuaian akibat supply kentang yang terus menurun menyebabkan peningkatan harga domestik, namun setelah supply stabil maka harga dapat ditekan. Namun dapat dilihat tekanan dari volume impor ini terus menekan hingga periode masa panen kentang domestik dan tahun-tahun berikutnya, artinya pemenuhan supply dengan kentang impor memiliki resiko mendorong harga produsen semakin rendah.

Dampak dari guncangan volume impor kentang terhadap produksi domestik memang menyebabkan penurunan harga, namun penurunan harga tersebut tidak terlalu besar. Hal ini dapat disebabkan karena kebanyakan kentang yang diimpor oleh Indonesia merupakan jenis kentang Atlantis yang merupakan jenis kentang yang digunakan di dalam industri ${ }^{3}$.

Kentang atlantis masuk ke dalam pasar konsumsi dalam bentuk kentang olahan, terutama french fries sehingga tidak memengaruhi langsung kentang Granula (kentang sayur) yang diproduksi lokal di Indonesia. Peningkatan impor kentang Granula oleh Indonesia kebanyakan berasal dari China dan Bangladesh berpotensi menimbulkan gejolak harga domestik ${ }^{4}$, namun sayangnya hal tersebut sulit tertangkap oleh model ini karena keterbatasan data untuk volume impor kentang yang menyamaratakan seluruh varietas kentang di dalam satu kode HS.

Gambar 3 kemudian melengkapi penjelasan dampak banjir impor berupa penurunan harga impor dalam pengaruhnya terhadap harga domestik. Baik harga produsen maupun harga

\footnotetext{
${ }^{3}$ http://www.tempo.co/read/news/2011/10/11/0903 60822/Indonesia-Hanya-Impor-Kentang-FrenchFries

${ }^{4}$ http://www.stabilitas.co.id/view_articles.php?arti cle_id $=391 \&$ article_type $=0 \&$ article_category $=8 \&$ $\mathrm{md}=54500 \mathrm{f} 35 \mathrm{a} 41 \mathrm{~d} 8 \mathrm{~d} 2 \mathrm{ef} 85 \mathrm{e} 67 \mathrm{~b} 60 \mathrm{e} 908 \mathrm{a} 8 \mathrm{~b}$
}

konsumen mengalami penurunan harga secara berangsur, dimana harga konsumen terkena dampak langsung penurunan harga mulai dari periode satu. Hal ini dikarenakan pengaruh dari harga impor lebih dahulu memengaruhi harga konsumen karena kentang impor masuk ke dalam pasar konsumen terlebih dahulu kemudian baru memengaruhi harga produsen domestik yang menyesuaikan harga dengan harga impor yang lebih rendah agar tetap bisa bersaing dalam mendapatkan konsumen.

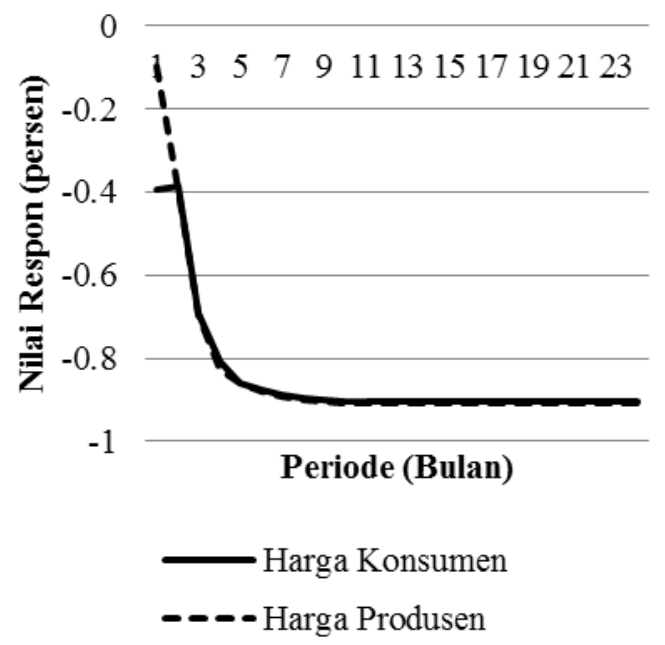

Gambar 3. Guncangan Penurunan Harga Impor Kentang terhadap Harga Domestik

Selain itu, banjir impor juga berdampak memberikan kontribusi pembentukan harga domestik seperti yang dapat dilihat pada Tabel 10. Pembentukan harga konsumen dan produsen kentang dipengaruhi oleh harga kentang impor sekitar 4\% sampai 5\%, namun pada harga produsen volume kentang impor turut memengaruhi harga produsen sebesar $5 \%$ hingga $6 \%$.

Hal ini dapat menggambarkan bahwa meningkatnya volume impor kentang di Indonesia secara tidak langsung akan menimbulkan persaingan dengan produksi kentang lokal. 
Tabel 10. FEVD Pembentukan Harga Domestik Kentang (dalam persen)

\begin{tabular}{ccccc}
\hline \multirow{2}{*}{ Tahun } & \multicolumn{4}{c}{ Harga Konsumen } \\
\cline { 2 - 5 } & PM & QM & PC & PF \\
\hline 1 & 4.47 & 1.12 & 90.75 & 1.02 \\
2 & 4.76 & 1.05 & 89.69 & 1.05 \\
3 & 4.85 & 1.03 & 89.36 & 1.06 \\
4 & 4.89 & 1.02 & 89.20 & 1.06 \\
5 & 4.92 & 1.01 & 89.11 & 1.07 \\
& \multicolumn{4}{c}{ Harga Produsen } \\
1 & 4.44 & 5.04 & 30.07 & 57.35 \\
2 & 4.76 & 5.86 & 30.37 & 55.00 \\
3 & 4.86 & 6.11 & 30.46 & 54.27 \\
4 & 4.91 & 6.23 & 30.51 & 53.92 \\
5 & 4.94 & 6.31 & 30.53 & 53.71 \\
\hline Ket: PM & $=$ hargay
\end{tabular}

Ket: $\mathrm{PM}=$ harga impor; $\mathrm{QM}=$ volume impor; $\mathrm{PC}=$ harga konsumen; $\mathrm{PF}=$ harga produsen

Walaupun kontribusi pembentukan harga domestik dari impor untuk beberapa komoditas tidak lebih dari sepuluh persen, dapat diamati seiring peningkatan tahun FEVD, terjadi peningkatan kontribusi dari impor tersebut dalam pembentukan harga domestik. Pada akhirnya dampak dari banjir impor selama tahun 2002 hingga 2012 ini terlihat dari dapat memengaruhi harga domestik secara permanen dan semakin meningkatnya pengaruh impor dalam pembentukan harga domestik.

\section{Rekomendasi Kebijakan dan Remedy SSM}

Peningkatan volume impor untuk komoditas hortikultura kentang dari semenjak keterbukan AFTA pada tahun 2002 terbukti mengakibatkan banjir impor (berupa peningkatan volume impor) pada komoditas-komoditas tersebut. Dampak dari banjir tersebut dapat secara permanen memengaruhi harga domestik, dimana penurunan harga produsen dapat mengurangi kesejahteraan petani. Persaingan dengan produk impor dengan harga yang lebih murah membuat petani mengurangi harga produknya lebih rendah lagi. Untuk itu, impor harus diredam.

Meredam impor secara teoritis dapat dilakukan dengan dua metode umum, yaitu pemberlakuan kuota impor atau peningkatan tarif impor. Penerapan kuota impor adalah membatasi sejumlah impor yang dapat dilakukan pada kurun waktu tertentu. Pada bulan September 2012, pemerintah menerapkan kebijakan kebijakan pembatasan pintu masuk untuk produk hortikultura berdasarkan Peraturan Menteri Perdagangan (Permendag) No. 30/M-DAG/PER/5/2012 tentang Ketentuan Impor Produk Hortikultura dan Peraturan Menteri Pertanian (Permentan) No. 60/PERMENTAN/OT.140/9/2012 tentang Rekomendasi Produk Impor Hortikultura. Berdasarkan kebijakan ini, impor hanya dapat masuk ke wilayah pabean Indonesia melalui empat pintu masuk, yaitu Bandara Soekarno-Hatta (Jakarta/Tangerang), Tanjung Perak (Surabaya), Pelabuhan Belawan (Medan), dan Makasar. Kebijakan ini didesain untuk meredam impor dengan mengecilkan pintu masuk atau bisa dikategorikan sebagai kuota impor atau kebijakan non tarif.

Pada tahun 2013, pembatasan impor hortikultura Indonesia menuai gugatan di WTO. Amerika Serikat menganggap pembatasan impor Indonesia merugikan ekspor AS ke Indonesia, hal tersebut dianggap AS melanggar aturan $\mathrm{WTO}^{5}$. Dalam hal ini, Indonesia beranggapan bahwa kebijakan tersebut diterapkan untuk melindungi petani lokal sehingga kebijakan tersebut wajar dilakukan bahkan oleh seluruh negara yang ingin melindungi perekonomian domestiknya ${ }^{6}$. Akibatnya, terjadi revisi kebijakan pada tahun 2013, dimana kuota impor

\footnotetext{
http://industri.kontan.co.id/news/kuota-impordaging-sapi-menuai-gugatan-di-wto

http://www.neraca.co.id/article/25680/SoalPembatasan-Impor-RIAS-Belum-Capai-TitikTemu
} 
digugurkan menjadi pembatasan impor berdasarkan indikator paritas harga berdasarkan Permendag No. 16/MDAG/PER/4/2013 tentang Ketentuan Impor Produk Hortikultura.

Selain kebijakan pembatasan impor (kuota), kebijakan tarif impor juga dapat meredam impor. Peningkatan tarif impor dari 5\% menjadi 25\% pada tahun 2005 di Indonesia untuk komoditas bawang merah dan jeruk menurunkan impor dan meningkatkan harga produksi, penurunan impor ini juga membuat produk lokal berpotensi ekspor (Saptana dan Hadi 2008). Di sisi lain, penurunan tarif impor pada tahun 2011 mengakibatkan penurunan harga produsen sebesar $16.1 \%$ untuk bawang merah dan $11.5 \%$ untuk jeruk (SEADI 2012).

Kebijakan peredaman impor dengan menggunakan metode kuota dan tarif impor mungkin efektif untuk mengurangi impor dan menyelamatkan kesejahteraan petani lokal, namun cara ini seringkali menuai klaim dari negara pengekspor asing terhadap Indonesia, terutama pelanggaran aturan WTO. Oleh karena itu, dibutuhkan perlindungan domestik yang sesuai dengan aturan WTO. Framework kebijakan Remedy SSM tepat diterapkan karena diterapkan berdasarkan peraturan WTO.

Secara teknis SSM menggunakan peningkatan tarif sebagai proteksi perekonomian domestik terhadap gempuran impor. Berdasarkan draft Modalities revisi Desember 2008, trigger dan remedy dari volume-based SSM dibagi menjadi tiga jenis, yaitu:

4. Ketika volume impor bernilai $110 \%$ namun tidak melebihi $115 \%$ (peningkatan volume $10 \%$ hingga $15 \%)$ terhadap base imports. Maka remedy yang digunakan adalah peningkatan tarif maksimal sebesar $25 \%$ dari bound tariff saat ini yang ditambahkan ke dalam applied tariff, atau 25 poin persentase ditambahkan ke dalam applied tariff secara langsung. Pilihan ditentukan dari tarif mana yang lebih besar.

5. Ketika volume impor bernilai $115 \%$ namun tidak melebihi $135 \%$ (peningkatan volume 15 hingga 35\%) terhadap base imports. Maka remedy yang digunakan adalah peningkatan tarif maksimal sebesar $40 \%$ dari current bound tariff ditambahkan ke dalam applied tariff, atau 40 poin persentase ditambahkan ke dalam applied tariff secara langsung. Pilihan ditentukan dari tarif mana yang lebih besar.

6. Ketika volume impor bernilai melebihi $135 \%$ (peningkatan volume lebih dari 35\%) terhadap base imports. Maka remedy yang digunakan adalah penerapan tarif sebesar 50\% dari bound tariff saat ini yang ditambahkan ke dalam applied tariff, atau 50 poin persentase ditambahkan ke dalam applied tariff secara langsung. Pilihan ditentukan dari tarif mana yang lebih besar.

Sedangkan untuk price-based, Trigger price-based SSM adalah penurunan harga sebesar $15 \%$ atau lebih (85\% atau kurang dari harga referensi). Tarif yang diberlakukan tidak lebih dari $85 \%$ gap antara harga impor dan harga trigger. Untuk kasus ketiga komoditas hortikultura dalam penelitian ini, tidak terjadi trigger price-based SSM kecuali untuk jeruk pada tahun 2004 dan 2005 sehingga lebih direkomendasikan untuk membentuk SSM berdasarkan volumebased SSM.

Misalkan pada penelitian ini, terjadi trigger B pada komoditas kentang dan jeruk pada tahun 2012, namun tidak terpicu trigger pada komoditas bawang merah, maka diputuskan pada tahun 2013 untuk memberlakukan SSM untuk kedua komoditas tersebut, maka perhitungan 
peningkatan tarif (berdasarkan data tarif WTO) adalah sebagai berikut:

Applied tariff Indonesia terhadap kentang adalah $20 \%$ dengan bound tariff sebesar 50\%. Berdasarkan SSM, peningkatan tarif terhitung adalah $40 \%$ dari bound tariff (50\%) ditambahkan kedalam applied tariff atau menambahkan 40 poin persen nilai ke dalam applied tariff, bergantung kepada nilai yang lebih besar. Pilihan peningkatan tarif adalah 40 persen atau 60 persen. jika diberlakukan SSM untuk komoditas kentang, pada tahun 2013 Indonesia dapat meningkatkan tarif untuk komoditas kentang hingga maksimal 60 persen ${ }^{7}$.

Perhitungan SSM ini merupakan rekomendasi kebijakan yang tetap sesuai dengan posisi Indonesia sekarang yang tidak lepas dari perdagangan internasional yang diawasi oleh WTO. SSM merupakan bentuk proteksi WTO terhadap negara berkembang, sebagaimana WTO tetap menginginkan hilangnya tarif perdagangan secara mutlak, disisi lain juga dilakukan proteksi dalam bentuk peningkatan tarif untuk melindungi produsen domestik dari gempuran impor.

Peningkatan tarif melalui SSM juga akan berguna untuk meredam importir atas volume impor yang meningkat terus menerus karena terjadi kenaikan biaya, di sisi lain juga meningkatkan harga barang impor sehingga tidak menggerus harga produsen domestik. Peningkatan tarif ini juga sesuai dengan pembuktian model VECM sebelumnya yang tertuang dalam output IRF dan FEVD bahwa tingginya

${ }^{7}$ Misalkan negara X memiliki $60 \%$ bound tariff dan 30\% applied tariff, negara tersebut memiliki dua pilihan yaitu:

$$
\begin{gathered}
(25 \% * 60 \%)+30 \%=45 \% \\
25 \%+30 \%=55 \%
\end{gathered}
$$

Maka pada saat terjadi peningkatan volume impor 10-15 persen, tarif akan dinaikkan sebesar 55\% Sumber:

http://www.wto.org/english/tratop_e/agric_e/guide _agric_safeg_e.htm impor saat 2002 hingga 2012 harus diredam, apabila peningkatan tarif ini nyata berpengaruh maka guncangan dari import surge dan price fall bisa diredam pengaruhnya terhadap harga domestik.

Disisi lain, pemberlakuan SSM juga dibatasi hanya untuk satu tahun dan tidak dapat dilakukan berturut-turut untuk produk yang sama. Berdasarkan Gambar 2 sampai 3 dapat dilihat bahwa fluktuasi yang tercipta akibat guncangan impor hanya bergerak selama satu tahun, setelah periode 12 hingga 24 nilai dari IRF bisa dikatakan stabil. Oleh karena itu SSM sudah tepat digunakan dalam jangka waktu setahun untuk meredam guncangan impor yang akan terjadi. Hal ini dapat menjadi rekomendasi yang baik bagi kebijakan perlindungan petani terhadap gempuran impor di Indonesia, terutama dengan memberikan insentif bagi pengimpor untuk meredam impor dengan peningkatan tarif. Sayangnya impor yang terjadi di Indonesia ditemukan berasal dari jalur tidak resmi, sehingga pemberlakuan tarif tidak berlaku bagi barang-barang ilegal tersebut dan seringkali terjadi pada komoditas hortikultura.

Komoditas hortikultura merupakan komoditas yang sangat rentan terhadap tindakan impor ilegal, dimana pada umumnya impor ilegal berasal dari pintu yang tidak ditetapkan atau pelabuhan yang berada di area free trade zone seperti Batam yang kebanyakan berasal dari China $^{8}$. Selain itu, pasokan bawang merah ilegal juga dapat melalui kapal-kapal kecil di sekitar sungai, dimana kapal tersebut mampu memuat hingga 2 ton bawang merah, pasokan ilegal ini berasal dari India yang masuk melalui Malaysia ${ }^{9}$.

\footnotetext{
8 http://bisnis.news.viva.co.id/news/read/467291kemtan--bawang-merah-produk-impor-ilegalterbanyak

${ }^{9} \mathrm{http} / / /$ medanbisnisdaily.com/news/read/2014/06/0 4/98598/bawang_merah_ilegal_semakin_der as_masuk_sumut/\#.U8R4i9zZZ7s
} 
kedekatan geografis juga dapat memancing oknum-oknum untuk mengakali perizinan impor. Misalnya pada tahun 2010 ditemukan impor jeruk ilegal yang berasal dari Pakistan dengan modus pemalsuan Surat Keterangan Asal (SKA) yang menyatakan bahwa jeruk tersebut berasal dari Malaysia ${ }^{10}$.

Impor ilegal menambah potensi adanya banjir impor karena impor masuk tanpa jalur resmi berdasarkan permintaan impor yang legal, menyebabkan tidak terkendalinya jumlah impor yang masuk ke dalam pasar domestik. Selain itu, impor ilegal juga tidak dapat menjamin tingkat kesehatan dari komoditas yang masuk, resiko komoditas mengandung bahan berbahaya sangat tinggi karena impor tidak dilengkapi dengan surat-surat. Impor ilegal juga merugikan negara karena tidak dapat menerapkan tarif untuk pemasukan negara dan perlindungan terhadap pasar domestik. Posisi impor ilegal diperburuk karena sulitnya deteksi masuknya impor ke Indonesia karena akses perairan Indonesia yang sangat luas.

Keberadaan impor ilegal harus diperhatikan karena kesuksesan program perlindungan domestik dengan penerapan tarif, misalnya SSM akan dapat efektif diterapkan apabila volume impor yang masuk tercatat dengan baik. Importir legal akan sangat keberatan apabila penerapan peningkatan tarif impor diterapkan kepada mereka yang mengimpor dengan legal, sementara produk-produk ilegal tetap masuk tanpa kendali apalagi tarif. Sinergi antara pengawasan masuknya impor berdasarkan syarat-syarat persuratan dengan kebijakan safeguard harus didahulukan untuk memulai perlindungan terhadap perekonomian domestik terutama petani dengan pemberlakuan peningkatan tarif berdasarkan SSM.

10 http://www.republika.co.id/berita/breakingnews/ekonomi/10/04/27/113054-jeruk-ilegalpakistan-masuk-lewat-malaysia

\section{SIMPULAN DAN SARAN}

\section{Simpulan}

1. Berdasarkan deteksi banjir impor melalui trigger SSM, volume-based SSM terpicu pada komoditas kentang pada sebagian besar tahun pengamatan. Artinya peningkatan volume selama tahun 2002 hingga 2012 dapat dikatakan sebagai banjir impor komoditas untuk komoditas kentang. Namun di sisi lain, price-based tidak terpicu karena tidak terjadi penurunan harga impor kentang selama tahun 2002 hingga 2012

2. Dampak banjir impor hortikultura, secara umum memengaruhi penurunan harga dan sifatnya permanen. Banjir impor juga sedikit berkontribusi terhadap pembentukan harga domestik namun kontribusinya meningkat seiring dengan berjalannya tahun.

\section{Saran}

1. Pembuktian banjir impor dan penerapan SSM sebaiknya menjadi agenda utama dalam rangka menekan impor walaupun penghapusan tarif impor diterapkan pada komoditas bawang merah, jeruk, dan kentang karena framework kebijakan ini telah diajukan oleh WTO.

2. Pengawasan ketat pintu masuk impor baik persyaratan pengimpor maupun jalur-jalur ilegal harus menjadi perhatian bagi Indonesia untuk mengawasi tingkat impor sesuai dengan kebutuhan.

3. Pemerintah juga harus mendorong produktivitas domestik untuk memenuhi kebutuhan domestik karena ketergantungan impor dapat menyebabkan perekonomian domestik semakin dipengaruhi faktor dari luar negeri. 


\section{DAFTAR PUSTAKA}

Aminuddin MF. 2009. Globalisasi dan Neoliberalisme: Pengaruh dan Dampaknya bagi Demokratisasi Indonesia. Jakarta (ID): Logung Pustaka.

[BPS] Badan Pusat Statistik. 2012. Data Ekspor-Impor. http://bps.go.id/eximframe.php?kat=2\&id_subyek $=08 \&$ nota $\mathrm{b}=50$ [diakses pada 13 Juni 2013]

2002-2012.

Statistik Harga Konsumen Pedesaan Kelompok Makanan. Jakarta [ID]: BPS

2002-2012.

Statistik Harga Produsen Pertanian Subsektor Tanaman Pangan, Hortikultura, dan Tanaman Perkebunan Rakyat. Jakarta [ID]: BPS

De-Nigris M. 2005 Statistical Analysis of Import Surges and Production Trends. FAO Import Surge Working Paper No. 2.

[FAO] Food and Agricultural Organization. 2005. FAO Trade Policy Technical Notes No.9 a Special Safeguard Mechanism for Developing Countries.

2011.

Agricultural Import Surges in

Developing Countries Analytical

Framework and Insights from Case Studies.

Firdaus M. 2011. Aplikasi Ekonometrika untuk Data Panel dan Time Series. Bogor (ID): IPB Press.

[Kemendag] Kementerian Perdagangan. 2012. Buku Menuju ASEAN Economic Community 2015. Jakarta (ID): Kemendag.

[Kementan] Kementerian Pertanian. 2013. Basisdata Ekspor-Impor Komoditi Pertanian.

http://database.deptan.go.id/eksim/inde x1.asp [diakses pada 23 Oktober 2013]

McCarthy J. 2000. Pass-through of Exchange Rates and Import Prices to Domestic Inflation in Some
Industrialized Economies. New York(US): Federal Reserve Bank of New York.

Mosoti V, Sharma R. 2005. The Interpretation of Various Impor Surge Related Concepts and Definition in the WTO Legal Text. FAO Impor Surge Project Working Paper no.3.

Prachason S. 2009. Impact of FTAs on Agriculture: Issues in Food Security and Livelihood. Asian Regional Workshop on Free Trade Agreements: Towards inclusive trade policies in post-crisis Asia 8-9 December 2009 The Twin Towers Hotel Bangkok.

[Pusdatin - Kementan] Pusat Data dan Sistem Informasi Petanian Sekretariat Jenderal - Kementerian Pertanian. 2013. Statistik Makro Sektor Pertanian 2013. Jakarta(ID): Kementan

Saptana dan PU Hadi. 2008. Perkiraan Dampak Kebijakan Proteksi dan Promosi terhadap Ekonomi Hortikultura Indonesia. Jurnal Agro Ekonomi Vol 26 No.1 Mei 2008: 21-46.

[SEADI] Support For Economic Analysis Development in Indonesia. 2012. Indonesian Horticultural Imports and Policy Responses. SEADI Project Report MOT http://www.seadiproject.com/post/repo rts/report-mot/indonesian-horticulturalimports-and-policy-responses/ (diakses pada 10 Juni 2014)

Setiyanto A. 2011. Analisis Special Safeguard Mechanism Komoditas Pangan Utama Indonesia dalam Rangka Perjanjian World Trade Organization [tesis]. Bogor(ID): Institut Pertanian Bogor.

Sharma R. 2005. Overview of Reported Cases of Import Surgers from the Standpoint of Analytical Content. FAO Import Surge Project Working Paper no.l.

World Bank. 2013. Global Economic Monitor (GEM) Commodities. http://databank.worldbank.org/data/dat 
abases/commodity-price-data [diakses pada 13 Juni 2013]

[WTO] World Trade Organization. 1999. Argentina - Safeguard Measures on Imports of Footwear. WT/DS121/AB/R

1999.

Korea - Definitive Safeguard Measure on Imports of Certain Dairy Products. WT/DS98/AB/R

2002.

Special Agricultural Safeguard Background Paper by the Secretariat Revision G/AG/NG/S/9/Rev1.

2008. An

Unofficial Guide to Agricultural Safeguards. 